\title{
DYNAMICS OF INTERNAL MOBILITY PROBLEMS IN ETHIOPIA: FACTORS AND CONSEQUENCES
}

\begin{abstract}
The main purpose of the paper is to investigate the influence of internal mobility on political social and economic problems in Ethiopia. In this research, major causes of internal migration and their ultimate consequences will be discussed based on the secondary data analysis and textual studies of documents. A new Constitution which was introduced in 1995, divided Ethiopia on ethnic lines into nine federal states and two multiethnic cities Addis Ababa and Diredawa. The state power was decentralized into separate administrative regions which created disputes of ethnic geographical locations. The influx of citizens from one regional state to the other, for different purposes mostly for permanent settlement, raised controversial problems which caused forced displacement of citizens. The analysis further tries to enlighten problems of the purposeful settlement intended for political gain in different towns and cities. In addition to the above, other factors causing internal displacement of citizens such as social and ethnic border conflicts, natural disasters, traditional internal mobility, as well as politically motivated conflicts contributing to internal migration and their consequences will be analyzed.
\end{abstract}

Keywords: Ethiopia, mobility, ethnic, border, conflict 


\section{THEORETICAL FRAMEWORK}

In this article the theory of push and pull factors are applied. This theory helps to explore various classical and contemporary problems of social mobilities within states as well as external mobility of persons. These factors include, economic crises, political instability, armed conflicts, wars, ethnic cleanings, social inequality, discrimination, natural disasters etc.

These theories could be the best tool to examine previous and existing situations of society and why they leave their place of origin or being influenced to other places. This basic framework enlightens combination of reasons that instigate or force a person to leave a place of origin (push factors) and causes that move a person to a particular geographical location or country (pull factors). Pull factors can be described as the reverses of the push factors, which is associated with better security, better prospects job or life (Stanojoska \& Petrevski (2012).

\section{INTRODUCTION}

Ethiopia is a federal state based on ethnic border lines. Chapter 4 of the 1995 Ethiopian constitution, Article 45 is a legal form of Government which constitutes the Federal Democratic Republic of Ethiopia. In accordance with Article 46 the Federation of Ethiopia is divided into States, on the basis of the settlement patterns, language, identity and consent of the peoples concerned. The member States of the Federal Democratic Republic of Ethiopia are mentioned as follows (Ethiopian Constitution, 1995):

1. The State of Tigray

2. The State of Afar

3. The State of Amhara

4. The State of Oromia

5. The State of Somalia

6. The State of Benshangul/Gumuz

7. The State of the Southern Nations, Nationalities and Peoples

8. The State of the Gambela Peoples

9. The State of the Harari People 
Article 47 of the constitution empowers nations, nationalities and peoples gives the right to establish, at any time, their own States, when the demand for statehood has been approved by a two-thirds majority of the members of the Council of the Nation, Nationality or People concerned, and the demand is presented in writing to the State Council and when the demand for statehood is supported by a majority vote in the referendum which enables to becomes a member of the Federal Democratic Republic of Ethiopia (Ethiopian Constitution, 1995). Even though Ethnic based federation satisfies the members of the community, it also generates endless conflicts and problems of internally displaced peoples linked with state boundary and ethnic related interests.

The problem of internally displaced people takes place mostly in mixed settlement zones as well as near population centers, providing chances to traders and service providers from all parts of Ethiopia. Displacement is also associated with ethnicity but also includes economic rivalry, aggravated by extended drought and unstable seasonal changes. Mostly local economic situation may determine the life of internal refugees. According to Mbiyozo, "If the local population feels disadvantaged by the resources provided to refugees, tensions can increase and communities might retaliate and prey on refugees. Local resentment can lead to more restrictive policies and in turn a higher risk of radicalization" (Mbiyozo, 2018). The range of the map of conflict areas and displacement include the Great Rift Valley reaching Tigray region to the north at the border to Eritrea; to the Somali region Jijiga and Dire Dawa populated by Oromos and Somalis where clashes have taken place between these communities. The most recent conflict in the Southern part of Ethiopia happened between Gedeo and Guji communities (J. Rücker, K. Kleinschmidt, M. C. Miller, 2019, p. 9), but the tensions between Guji and Gedeo communities in 2020 remained low as the result of reconciliation attempts(OHA, Ethiopia, 2020). Other significant factors of displacement in Ethiopia include-natural disaster-induced displacement; movements and needs of pastoralist communities; and direct Conflict-induced Displacement, Development-induced displacement which imposes eviction of inhabitants or villagers. Commercial farm developments, road and railway constructions are also classified as factors of displacement. Generally, the socio-economic and the process of transformation generates push and pull factors for populations 
mobility and often leads to conflict. Consequently, the present displacement condition in Ethiopia is multi-dimensional and needs resolutions outside a merely humanitarian method. There are several motives of conflict-induced movement, among them: resource shortage; droughts; problem of grazing and cultivation land; conflicts between pastoralists and farmers; administrative boundary problems between regions; Cross-border, ethnic conflicts; and lack of conflict management mechanisms (Rücker, Kleinschmidt, Miller, 2019, p. 10; Migration data in Eastern Africa, 2020; Maru M. T. 2018, p.18-19; Debebe, 2016, p.34-36).

Ethiopia is categorized as world's largest displacement of people in 2019. This situation is thought to be one of the major problems of reforms planned by prime minister Abiy Ahmed, who came to power in 2018 (Wilson, 2019). In the southern part of Ethiopia, according to the UN sources, the conflict between Gedeo and Guji have displaced more than 700,000 people. The number of the people displaced in Ethiopia have been estimated to be total, 2.9 million people, which is higher than that of displaced people in Syria, Yemen, Somalia and Afghanistan combined together.

On the other hand, more than 200,000 ethnic Oromos have been expelled from the western Benishangul-Gumuz region since September 2019. The Benishangul state accused members of another ethnic group, the Amhara, of killing more the 200 people in a territorial dispute. Similar disputes have flared on Oromia's eastern border with the Somali region (Wilson, 2019). Uncertainty and conflict in Metekel Zone, has been deteriorating since 2019. The situation in the region has been intensified in recent months. Following this problem the federal Government of Ethiopia declared a State of Emergency the conflict Zone in January 2021. From the Early July 2020, attacks by unidentified armed groups caused displacement of 150,000 people in Bullen, Dangur, Dibate, Guba, Mandura and Wombera woredas, representing over 30 per cent of the total population of Metekel Zone (Reliefweb, Ethiopia: Metekel Zone, Flash Update No. 2 (29 January 2021). 


\section{CONFLiCT AND DISPLACEMENT PROBLEMS IN ETHIOPIA}

Global Report on Internal Displacement (GRID) compared global conflict consequences of displacement, in which Ethiopia was noted as the highest number of new internal displacements in 2018. Political crisis has been expanding increasingly since 2016, and interethnic conflict intensified and spread to new areas. This problem caused nearly 2.9 million new displacements, which was thought to be four times the number for 2017. According to Global Report on Internal Displacement (GRID), "conflict and displacement were recorded along three of the Oromia region's borders, with the Southern Nations, Nationalities and Peoples' (SNNP) region in the south-west, the BenishangulGumuz region in the north-west and the Somali region in the east"' (GRID, 2019 p.14.). Displacement included city centers such as Addis Ababa and Jijiga, the capital of the Somali region. Exceptional rise in new dislocation of people was instigated by significant political change in Ethiopia, after a new prime minister came to power in April 2018. The new administration changed the country's state, released all political prisoners, ended the state of emergency and started a peace agreement with Eritrea. The new government changed previous practices including unnecessary use of force and restriction of protests and showed willingness to cooperate with aid agencies concerning humanitarian supplies. This shows that (GRID, 2019, Ibid.), the new administration in Ethiopia has recognized the presence of conflict induced IDPs in Ethiopia which was impossible during the previous government.

Sub-Saharan Africa region was once again the regions most affected by conflict displacement in 2019, as the result of armed conflict, communal violence. Among 5 countries Ethiopia had the most new displacements of 1,556,000 persons. (Global Report on Internal Displacement (GRID, 2020, P.15.)

According to USAID, there are problems of insecurity throughout Ethiopia as the reason of rapid population displacement. This creates humanitarian needs, and delay relief organizations from distributing life-saving support. About 80 percent of the 2.9 million internally displaced persons (IDPs) recognized throughout Ethiopia have been motivated by conflict as the principal factor of displacement. Poor infrastructures in the country are also one 
of the problems to reach affected areas by humanitarian agencies to aid (USAID, 2019, Ibid.).

The data gathered by Displacement Tracking Matrix and IOM with joint collaboration of National Disaster Risk Management Commission (NDRMC) conducted between 2 January and 6 February 2018, shows a total of 1,737,752 persons displaced by climatic and conflict factors in Ehiopia. The study further states that, IDPs settled in 916 sites in different parts of the country. According to the collected data, as the result of conflict and tensions 70\% these IDPs, that means around 1,222,123 persons, have been displaced from the place of their origin (reliefweb, 2018). On the other hand, tensions between Somali and Oromo communities as well as conflict along the boundary separating the two regions has displaced around 1.070 million IDPs. This amounts more than $87 \%$ of the total number of conflict-IDPs noted in the meantime. These Displaced people are located in 439 sites: (reliefweb, 2018).

- The highest concentration of conflict IDPs are hosted in East Hararghe (210,000 persons)

- Dawa zones (188,000 persons)

- The Qoloji IDP sites host around 80,000 persons

Furthermore about 144,000 persons displaced from Jijiga and other urban centers in Somali region in September 2017 are reported living in 204 different sites in Oromia, Dire Dawa and Harar, among them 43,000 were hosted in 29 shared or transit centers. According to DTM-9 98 additional new sites and most of which having been set-up before November 2017, were hosting some 206,200 persons displaced because conflict along the boundary areas of Oromia and Somali regions (reliefweb, 2018).

Ethiopia's National Displacement Report in its findings of July 2021, assessed displacement causes. The Site Assessment (SA), reveals that a total of 1.96 million IDPs were identified in 1,379 sites within 11 regions in Ethiopia. Among this, conflict displaced an estimate of 1.25 million IDPs, drought displaced 318,992 IDPs, flash floods which displaced 156,815 IDPs and seasonal floods which displaced 113,388 IDPs (Ethiopia, National Displacement Report 8 March, April 2021). 


\section{IDPS IN WESTERN ETHIOPIA}

In Benishangul Gumuz region and in East and West Wollega zones of Oromia region, vicious violence have been broke out which displaced nearly 250,000 persons since September 2018, (OCHA, Ethiopia 2018). Since April 2018, tremendous changes have been taking place in Ethiopia regarding political, civic and human rights reforms. Mass complaints and protests that had overwhelmed the country since 2015, and have given optimism to Ethiopians, but the new political change is not complete and faces serious tests. Most challenges are based on inter-communal violence across the country which led to mass internal displacements, loss of lives and damages. Inter-ethnic conflicts have always been one of the significant problems, but recently the scale and frequency of the violence are extraordinary (OCHA, Ethiopia 2018).

According to OCHA about 1.4 million people were displaced by conflict in 2018, of which approximately 1 million were in Gedeo-West Guji in southern Ethiopia. The total number of displaced people in 2018 was estimated to be 2.8 million. Among these 82 per cent of IDPs are caused by conflict, and the remaining 18 per cent are caused because of climate changes. The main reason of new wave of violence and displacement in western part of Ethiopia was happened on 26 September 2018 incident in which four high-ranking state officials of Benishangul Gumuz were killed in Oromia, near the regional frontier. Following the incident, inter-ethnic conflict erupted in Kamashi zone (Benishangul Gumuz region) between the Gumuz community and the ethnic Oromo and Amhara inhabitants living in the region. This caused displacement, loss of life, grievances between these communities. The central government intervention to bring peace and security have been unsuccessful. OCHA, estimated the number of displaced people to be 250,000 inside Benishangul Gumuz region, among this, 15,000 in Oda woreda, Assosa zone and 42,000 in Kamashi zone) and across the border in Oromia region 101,000 in East Wollega zone and 81,000 in West Wollega zone, (OCHA, Ethiopia 2018). Due to the worsening security conditions in the area, aid organization access and lifesaving assistance to the 28,000 returnees and 101,000 new IDPs was reported to be difficult, but the regional Government was doing its best to provide lifesaving assistance since July 2020 using armed bodyguards, which was inadequate (OCHA, ETHIOPIA: Benishangul Gumuz Region Flash Update 6 January 2021). 


\section{IDP RETURNEES IN WESTERN PART OF ETHIOPIA}

In the western part of Ethiopia, inter-ethinic conflict had erupted in Kamashi zone on 26 September 2018. Huge number of people have been displaced, including women and children. The IDPs got save heaven in East \& West Wellega where they stayed in collective sites. Among these, 145, 685 IDPs were living in East Wellega and 83,269 IDPs were living in West Wellega. Evidence from the reliefweb, shows that, from these collective sites, some of them have decided to return to their place of origin (OCHA, Ethiopia East and West Wellega zone, 2018):

- In East Wollega, 89,265 IDPs have returned to their place of origin.

- 26,985 IDPs have returned to their place of origin in Yaso and Belo Jeganfoy woredas of Kamashi Zone (BGR) from East Wellega Zone.

- Overall,80\% of the IDPs from East Wollega have returned to their place of origin along the border of Oromia region and Kamashi zone.

- $20 \%$ of the IDPs are living within the host community.

- In West Wollega, 50, 555 IDPs have returned to their place of origin in Oda Bildigilu Woreda of Assosa Zone and Sedal, Agelo Meti and Kamashi Woredas, Kamashi Zone.

- 29,265 IDPs from West Wollega zone have returned to their place of origin along border areas of Oromia region.

- Overall, 94\% IDPs from West Wollega have returned to place of origin along the border of Oromia region and Assosa \&Kamashi zone.

- $6 \%$ of the IDPs $(3,449)$ were living in the collective sites. 
Table 1.

Number of IDPs returnees to their place of origin in 2019.

\begin{tabular}{|c|c|}
\hline \multicolumn{2}{|c|}{ Number of IDP returnees per Woreda (District) } \\
\hline Sasiga & 39,051 \\
\hline Haro Limu & 30,468 \\
\hline Yaso & 26,710 \\
\hline Oda Bilidigilu & 14,473 \\
\hline Agelo Meti & 14,020 \\
\hline Kamashi & 12,745 \\
\hline Sedal & 9,802 \\
\hline Belo Jeganfoy & 9,743 \\
\hline Gimbi & 7,196 \\
\hline Lata Sibu & 5,986 \\
\hline Najo & 5,187 \\
\hline Guto Gida & 4,535 \\
\hline Mana Sibu & 4,480 \\
\hline Boji Dermiji & 4,044 \\
\hline Limu & 2,592 \\
\hline Diga & 848 \\
\hline Gida Ayana & 354 \\
\hline Lalo Asebi & 298 \\
\hline Leka Dullecha & 154 \\
\hline
\end{tabular}

Source: Ethiopia East \&West Wellega zone(Oromia Region)and Kamashi zone(BGR) IDP Returnees Snapshot, 31 May 2019, https://reliefweb.int/sites/reliefweb.int/files/resources/31052019_west_ east_wellega_kemashi_assosa_bgr_idp_returnees_snapshot.pdf

Generally the data collected between December to January 2021 in Ethiopia, there were an about 1.5 million returning IDPs (267,583 households) across 1,381 settlements in Ethiopia. The huge number of returning IDPs is predominantly due to government-led return activities which was launched in April 2019 (DTM Ethiopia National Displacement Report 7, 2021, p.33.). 


\section{Political ASPects of Displacement in Ethiopia}

Ethiopia is one of the populous countries in Africa, this country had maintained its freedom from colonial rule during the second world war, but external factors such as wars with Somalia and Eritrea as well as interethnic conflicts are the major problems of displacement of citizens in Ethiopia. After 1974 a military coup, in which Emperor Haile Selassie was overthrown, Ethiopia faced serious internal and external problems which caused displacement of citizens. The first is the Ethiopia-Somali disagreement over the Ogaden region, which led to war for two years (Mberu, 2006, p. 511). According to Gebru Tareke, the Democratic Republic of Somalia entered Ethiopia in mid-1977 to fulfil its dream of getting back the Ogaden region of Ethiopia which it claims as part of Somalia, thought to be a first step toward the creation of a Greater Somalia with the Somali people in the Horn of Africa (Tareke, 2000, p. 635.).

Following its independence in 1960, Somalia claimed the Haraghe and Bale regions of southern Ethiopia (Waal, 1991). The Somali army invaded Ogaden on July 23,1977 . The army was frequently brutal and abusive to the residents of the areas it controlled. It was dealing with ethnic Oromo civilians severely and treated them worse than ethnic Somali. Somali soldiers committed different types of mishandlings and violations of human rights, among others, (Waal, 1991, p. 75):

- destroying or looting property, and on occasion killing the owners who protested. Soldiers raping women, and killing brothers, husbands or fathers who objected.

- taking food or livestock to eat, and sometimes killing the owners who objected.

- opening fire on civilians who returned to investigate the condition of their houses or farms which had been occupied by soldiers.

As the result of the above-mentioned problems and counter-offensive, 500,000 people were internally displaced within Ethiopia, and others took refuge to the neighboring countries (Waal, 1991, p. 78).

Various problems occurred after the takeover of the military government in Ethiopia in 1974. Among others, the conflict between central Ethiopian government and separatist movements for independence of Eritrea and other 
political movements in the country. Devastating civil war spread across the country, mostly in the Somali region of Ethiopia, including the Afar and Oromo as well as Tigray rebels in the northern part of the country. The military government known with its brutality and political repression led to large loss of life and property and massive internal displacements. This problem placed Ethiopia as one of Africa's largest producers of refugees during the early 1990s. Ethiopia also faced severe droughts in different periods. These happened in the years 1977-78, 1984-1985,1987-1988, and 1993-1994 (Mberu, 2006, 511). The most disastrous famine took place in 1984-1985. As the result of this catastrophic famine of the 20th century, more than a million citizens of Ethiopia have lost their life. To reduce the effect of famine during 1984-85 about 600,000 people have been displaced following the resettlement program. Victims of hunger and drought from the northern and central Ethiopia were settled in the western part of Ethiopia. The military government of Ethiopia as the response to tackle the problem of famine and drought launched a huge national relocation and villagization program. The new resettlement program has been opposed by previous inhabitants and led to ethnic and cultural conflicts (Mberu, 2006, 511-512).

\section{Conflict between Amara And Qemant COMMUNITIES IN NORTHERN ETHIOPIA}

Violent tensions and irregular conflict between the Amhara and Qemant communities instigated in September 2018 across the Central and West Gondar zones of the Amara administrative region. This conflict caused displacement of about 56,000 people up to February 2019. Amara Regional Disaster Prevention and Food Security Coordination Office (RDPFSPCO), in association with sector bureaus, NGOs and UN agencies, helped affected areas in October 2018. The investigation recognized an estimated 6,000 IDPs, who were newly displaced in September 2018. By December 2018 however, the regional government announced that the figure of displaced people in the region had been estimated to be 43,000, which subsequently need more for IDPs from December 2018 to May 2019. According to the 
authorities, continuous conflict displaced civilians from their homes, which increased the number of IDPs in the region to 90,000 in February 2019. About 60,000 of this people are displaced from Central and West Gondar zones. Displaced Amharas also come from other regions of Ethiopia, for example, from Oromia (Buno Bedele, Jimma, Nekemt and Kelem Wollega zones), Benishangul Gumuz (Kamashi zone), SNNP (Bench Maji zone), Afar, Somali and Tigray regions begning from October 2017. The IDPs are dispersed across 11 zones (Amhara Flash, 2019, p.1).

Table. 2.

Scattered IDPs in 11 zones Amara region in 2019.

\begin{tabular}{|l|l|}
\hline Central Gonder & 49,312 \\
\hline West Gonder & 7,480 \\
\hline South Gonder & 3,088 \\
\hline North Wollo & 3,275 \\
\hline South Wollo & 2,097 \\
\hline Oromo zone & 4,760 \\
\hline West Gojam & 15,842 \\
\hline North Shoa & 516 \\
\hline Wag Hemira & 236 \\
\hline Awi & 2,919 \\
\hline East Gojam & 1,211 \\
\hline
\end{tabular}

Source: Amhara Flash, 01 March 2019 https://reliefweb.int/report/ethiopia/amhara-flash-update-01-march-2019

As of 01 March 2019, more than 90,000 people were displaced in Amhara region, most of them since September 2018. 70\% IDPs are living with host communities in temporary, and in sub-standard settlement sites $30 \%$. Like in other parts of Ethiopia, the IDPs lack primary needs-enough access to basic services such as food, water and sanitation, education, health and shelter. The priority need expressed by IDPs was security and protection, before food, shelter and household stuffs. UN Office for the Coordination of Humanitarian Affairs indicate that all IDP sites in Central Gondar are accessible, while some sites in West Gondar remain cannot be reached due to security alarms on the 
road. Basic social services such as-schools, health, and other Government services were also suspended due to insecurity problems (OCHA, 2019, p. 1). Following the internal displacement related to the Northern Ethiopia Crisis in Amara, Tigray and Afar regions in June 2021, Displacement Tracking Matrix (DTM) deployed its Emergency Site Assessment and discovered that 2,105,387 IDPs (449,492 households) have been displaced from their original locations (Ethiopia, Emergency Site Assessment 7, (1-26 June 2021)

\section{MOBILITY INCLINATIONS AND REASONS OF DISPLACEMENT}

Displacement Tracking Matrix (DTM) Amhara Region, Ethiopia, states that conflict has been frequently specified as the main reason of displacement in the region as specified in table 3. IDPs displaced before and during 2018 were mainly displaced by conflict. In addition to this, $36 \%$ of IDPs reported being displaced previously.

Table. 3.

Distribution of IDPs by cause of displacement and time of displacement

\begin{tabular}{|c|c|c|c|}
\hline Duration & Conflict Induced & Climate Induced & Total \\
\hline Before 2018 & 10,076 & 152 & 10,228 \\
\hline During 2018 & 13,339 & 109 & 13,448 \\
\hline Total & 23,415 & 261 & 23,676 \\
\hline
\end{tabular}

Source: Displacement Tracking Matrix (DTM) Amhara Region, Ethiopia Summary of Key Findings Round 15: January/February 2019, 26 March 2019, https://reliefweb.int/sites/reliefweb.int/files/resources/ Round\%2015\%20Amhara.pdf

This indicates a significant level of mobility amongst the displaced population. Besides that, IDPs from 27 sites showed their willing to leave the current place of displacement. Among these, IDPs from 5 sites wanted to settle in the nearest village and IDPs from 1 site planned to go back to their previous destination (DTM, 2019 p. 4).

The need for an additional migrant tracking survey was strongly recommended to find information on migrant outcomes at the destination, and information on the migrant and the source household prior o the move. This 
helps to measure changes in welfare over time for individuals that stay and move from a fixed place, conditioning on individual and household level characteristics (Brauwa A. D., et al, p. 348.).

On other hand, Displacement Tracking Matrix (DTM) focusing on Amhara region of Ethiopia as of February 2019, indicated that, desire for durable solutions, at $53 \%$ of sites IDPs expected a resolution to their displacement, while IDPs at $47 \%$ of sites preferred another solution.

Table. 4.

\section{Individuals with specific vulnerabilities}

\begin{tabular}{|l|c|}
\hline \multicolumn{1}{|c|}{ Vulnerable Population } & Number of IDPs \\
\hline Number of breastfeeding mothers & 2,772 \\
\hline Elderly-headed households & 79 \\
\hline Elderly persons without caregivers & 141 \\
\hline Number of members of religious minorities & 30 \\
\hline Orphaned children & 92 \\
\hline $\begin{array}{l}\text { Persons with chronic diseases/ serious medical } \\
\text { conditions }\end{array}$ & 94 \\
\hline Number of persons with disabilities over & 18109 \\
\hline Number of persons with disabilities under & 1853 \\
\hline Number of pregnant girls under & 1860 \\
\hline Number of pregnant women over & 181,227 \\
\hline Separated children & 92 \\
\hline Single female-headed households & 1,112 \\
\hline Single male-headed households & 422 \\
\hline Unaccompanied Children & 59 \\
\hline Single child-headed Households & 44 \\
\hline Total & 6,486 \\
\hline
\end{tabular}

Source: Displacement Tracking Matrix (DTM) Amhara Region, Ethiopia Summary of Key Findings Round 15: January/February 2019, 26 March 2019, https://reliefweb.int/sites/reliefweb.int/files/resources/ Round\%2015\%20Amhara.pdf

At $46 \%$ of sites, IDPs prefer reintegration as a durable solution to their displacement while at $20.3 \%$ sites they favor return. $33.8 \%$ of sites reported that IDPs wish relocation ((DTM, Amara Region, 2019) 


\section{The PROBlem Of GEDEO AND West GUJi ZONE}

According to IOM, the UN Migration Agency, displacement report, in Ethiopia’s Gedeo and West Guji zones, 958,175 people have been displaced following interethnic conflicts. IOM led the analysis of displacement sites in both zones. The result of the investigation reveals that about 359,113 people were sheltering in collective sites. The rest of the displaced population were living with local communities, in rented lodging, or with relatives, but still staying in contact with collective sites to get humanitarian backing. The conflict started In March 2018, because of the clashes between people along the boundary of two Ethiopian administrative regions of Southern Nations, Nationalities, and Peoples' Region (SNNPR) and Oromia Region. As hostilities intensified in June, hundreds of thousands of people escaped their homes leaving behind all their entire property (IOM UN Migration, 2018). The IOM investigation with close coordination of the Ethiopian Administration stated that, West Guji administrative zone was the zone of origin of the largest group of displaced people while, more specifically, indicating Kerca as the major district of displaced people. The assessment also confirms that in Gedeo zone, among the majority of the 970,000 displaced people, at least 276,939 people were living in 134 collective sites. The collective sites include schools, government buildings, and abandoned or uncompleted houses. Furthermore, the study displays that in seven of the sites, more than half of the people are living outside or in open spaces. The cold and rainy season, in Ethiopia, has been an additional problem for displaced people and a serious challenge for authorities to address and 19 of the 134 are inaccessible by car, making humanitarian aid distribution extremely tough (IOM UN Migration, 2018). 


\section{RECENT ETHNIC CONFLICT AND IDP CRISIS IN ETHIOPIA}

An estimated million ethnic Gedeos and Gujis (Oromos) were displaced because of the inter-ethnic conflict between the two bordering communities since April 2018 (Ethiopia Humanitarian Bulletin, 2019). The Prime Minister of Ethiopia, Abiy Ahmed met IDPs in Gedeo zone, the southern part of Ethiopia region and promised that his Government will scale up life-saving assistance for the affected population. He also promised to safeguard a lasting solution to the intercommunal conflict displacement crisis. The IDPs expressed their complaints because of the inadequate humanitarian assistance they've received so far. High-level Government officials including Minister of Peace and Commissioner Mitiku Kassa of the National Disaster Risk Management Commission, addressed the problem of thousands of needy IDPs concerning shelter and other basic needs for displaced people. The circumstances have been particularly terrible in the conflict region where, IDPs were deprived of any assistance for the past 8 months because of difficulties in humanitarian access to the region. The IDPs, were affected as the result of malnutrition and high risk of an outbreak of disease has been reported. These people have suffered frequent displacements from their areas of origin and need stronger safety guarantees before they return to their region (Ethiopia Humanitarian Bulletin 2019, p.1.). The international community is also involved to support IDPs, following the opening of access to the location of Gedeo zone administration. Civilians in Gedeo, continued to survive the most terrible conflict, risking their safety within their locations of displacement. Fighting has pushed IDPs to move from their original area to another location numerous times and subjected them to higher security threats. About 3,000 have been said to be newly displaced from Liben to Negelle town and 80,000+ IDPs have faced shortage of food assistance since March 2020. This happened because of intimidation and physical assault on aid workers from perpetrators of the conflict. (OCHA, ETHIOPIA Access Snapshot-Guji zone (Oromia region, 2021). 


\section{Conclusion}

The scale and difficulty of internal displacement in Ethiopia need durable solutions. Escalation of the ongoing conflict may lead to economic decline and political instability. Collaboration with humanitarian and development organizations could be important, but the large part of the problem must be addressed by Ethiopian authorities and Ethiopian citizens. The role of humanitarian support is to enhance the efforts of national governments, responsible to tackle the root causes of conflicts. Religious leaders, elders, federal and regional authorities at all levels, need to seek ways and strategies to build peace and stability between conflicting parties focusing on specific and unique problems concerning disputes between communities or different ethnic groups. Present conflicts and displacement of peoples must stop soon to bring peace and prosperity to Ethiopia. 


\section{REFERENCES}

Amara, Flash. (2019). https://reliefweb.int/report/ethiopia/amhara-flash-update-01march-2019

Brauwa, A. D., Muellera, V. B., Woldehanna T., (2018). Journal of African Economies, Vol. 27, number 3, p. 348.

Debebe, A. (2016). Mobility and Conflict: Persistent Challenges in Expanding Access to Education Among Pastoralists of South Omo, Ethiopia. Ethiop. J. Educ. \& Sc. Vol. 11 No 2, p. 34-36.

DTM. Ethiopia National Displacement Report 7 Site Assessment Round 24 \& Village Assessment Survey Round 7: December 2020-January 2021. https://displacement.iom.int/sites/default/files/public/reports/DTM\%20Ethiopia\%20National\%20 Displacement\%20Report\%207\%20\%28Compressed\%29.pdf

DTM. Amhara Region, Ethiopia Summary of Key Findings Round 15: January/ February 2019. 26 March 2019, p. 4. https://reliefweb.int/sites/reliefweb.int/files/ resources/Round\%2015\%20Amhara.pdf

Ethiopia. Emergency Site Assessment 7, (1-26 June 2021). https://dtm.iom.int/reports/ ethiopia-\%E2\%80\%94-emergency-site-assessment-7-1-\%E2\%80\%94-26-june-2021

Ethiopia-National Displacement Report 8 March-April 2021. https://dtm.iom.int/reports/ethiopia-\%E2\%80\%94-national-displacement-report-8-march-\%E2\%80\%94april-2021

Ethiopia Humanitarian Bulletin Issue 5, 4-17 March 2019, p.1.

Ethiopian Constitution (1995).

Global Report on Internal Displacement (GRID). (2020). P.15. https://www.internal-displacement.org/sites/default/files/publications/documents/2020-IDMC-GRID. pdf

Global Report on Internal Displacement (GRID). (2019). Ethiopia New waves of conflict cause unprecedented displacement, 5.06.2019, p. 14.

http://www.internal-displacement.org/sites/default/files/publications/documents/2019-IDMC-GRID-spotlight-ethiopia.pdf

IOM UN Migration. UN Migration Agency Releases Detailed Assessments of Displacement Sites in Ethiopia's Gedeo. West Guji, 14.08.2018. www.iom.int/news/ un-migration-agency-releases-detailed-assessmentsdisplacement-sites-ethiopias-gedeo-west-guji

Maru, M. T. (2018). Maru Causes, Dynamics, and Consequences of Internal Displacement in Ethiopia. berlin.org/fileadmin/contents/products/arbeitspapiere/ Maru_2017_Internal_Displacement_Ethiopia.pdf, p. 18-19.

Mberu, B. U. (2006). Demographic Research: Volume 14, Internal migration and household living conditions in Ethiopia. Max-Planck-Gesellschaft, p. 511. https:// www.demographic-research.org/volumes/vol14/21/14-21.pdf 
Mberu, B. U. (2006). Demographic Research: Volume 14, Internal migration and household living conditions in Ethiopia. Max-Planck-Gesellschaft, p. 511 - 512. https://www.demographic-research.org/volumes/vol14/21/14-21.pdf

Mbiyozo, A. N. (2018). Fleeing terror, fighting terror: the truth about refugees and violent extremism. Fleeing terror, fighting terror: the truth about refugees and violent extremism-ISS Africa https://www.swp-

Migration data in Eastern Africa, https://migrationdataportal.org/de/regional-data-overview/eastern-africa

OCHA, Ethiopia: Benishangul Gumuz Region Flash Update 6 January 2021. https:// reliefweb.int/sites/reliefweb.int/files/resources/ethiopia_benishangul_gumuz_metekel_flash_update_06_01_2021.pdf

OCHA, Ethiopia Access Snapshot-Guji zone (Oromia region). https://www.humanitarianresponse.info/sites/www.humanitarianresponse.info/files/documents/files/ ocha_access_210517_snapshot_guji_zone_oromia_may_2021.pdf

OHA, Ethiopia, Access Snapshot-Gedeo and West Guj. https://www.humanitarianresponse.info/sites/www.humanitarianresponse.info/files/documents/files/ocha_ethiopia_200930_access_snapshot_gedeo_west_guji_september_2020.pdf

OCHA Ethiopia, Internal Displacement around Kamashi and Assosa (Benishangul Gumuz) and East and West Wollega (Oromia) 26 December 2018. https://reliefweb.int/sites/reliefweb.int/files/resources/Operational-plan-for-rapid-responseto-Kamashi-and-Assosa-8.pdf

OCHA, Ethiopia East \&West Wellega zone(Oromia Region)and Kamashi zone(BGR) IDP Returnees Snapshot, 31 May 2019. https://reliefweb.int/sites/reliefweb.int/ files/resources/31052019_west_east_wellega_kemashi_assosa_bgr_idp_returnees_snapshot.pdf

Reliefweb, Ethiopia: Conflict-induced displacement Situation Report No. 317 April 2018. https://reliefweb.int/sites/reliefweb.int/files/resources/ethiopia_ - _conflict_induced_displacement_sitrep_3_-_17_april.pdf

Reliefweb, Ethiopia: Metekel Zone, Benishangul Gumuz Region, Flash Update No. 2 (29 January 2021). https://reliefweb.int/report/ethiopia/ethiopia-metekel-zone-benishangul-gumuz-region-flash-update-no-2-29-january-2021

Rücker, J., Kleinschmidt K., Miller, M. C. (2019). Creating Sustainable Development Zones in Ethiopia Proposal for a bankable "SME City" pilot project as a model for optimized local governance for all social groups including Internally Displaced Persons (IDPs) Unhabitat, p. 9.

Rücker, J. (2019). Kleinschmidt K., Miller M. C., Creating Sustainable Development Zones in Ethiopia Proposal for a bankable "SME City" pilot project as a model for optimized local governance for all social groups including Internally Displaced Persons (IDPs) Unhabitat, p. 10. 
Stanojoska, A., Petrevski, B. (2012). Theory of push and pull factors: a new way of explaining the old. https://www.academia.edu/2163849/theory_of_push_and_pull_ factors_a_new_way_of_explaining_the_old

Tareke, G. (2000). The Ethiopia-Somalia War of 1977 Revisited International Journal of African Historical Studies,2000, Vol. 33, No. 3. p. 635.

USAID, Ethiopia 20.06. 2019. https://www.usaid.gov/crisis/ethiopia

Waal, A. D. (1991). Evil Days: Thirty Years of War and Famine in Ethiopia, Human Rights Watch New York, p. 75. https://www.hrw.org/sites/default/files/reports/ Ethiopia919.pdf

Waal, A. D. (1991). Evil Days: Thirty Years of War and Famine in Ethiopia, Human Rights Watch, New York, p. 78. https://www.hrw.org/sites/default/files/reports/ Ethiopia919.pdf

Wilson, T. (2019). Ethiopian ethnic violence has forced almost $3 \mathrm{~m}$ to flee homes, 26 May 2019. https://www.ft.com/content/0fa7e73e-7afe-11e9-81d2-f785092ab560

Wilson, T. (2019). Ethiopian ethnic violence has forced almost $3 m$ to flee homes, 26 May 2019. https://www.ft.com/content/0fa7e73e-7afe-11e9-81d2-f785092ab560 